\title{
Isolation of Phytase Producing Bacteria and Optimization of Phytase Pro- duction Parameters
}

\author{
Nand Kumar Singh ${ }^{1,{ }^{*}}$, Dharmendra Kumar Joshi ${ }^{1}$, Raj Kishor Gupta ${ }^{1}$ \\ ${ }^{1}$ Department of Biotechnology, Motilal Nehru National Institute of Technology, Allahabad, India \\ ${ }^{*}$ Corresponding author: Nand Kumar Singh, Motilal Nehru National Institute of Technology, Allahabad U.P. 211004, India. Tel: +91-05322271200, Fax: +91-05322271200, E-mail: singh- \\ nand@gmail.com.
}

Received: May 19, 2012; Revised: July 31, 2012; Accepted: August 08, 2012

\begin{abstract}
Background: Cereals, legumes, and oilseed crops are very important crops as nutrition for human and animals. Phytate (myo inositol hexa kis phosphate) is the main storage form of phosphorus in these crops. These crops are major source of nutrients for humans and animals including fish, poultry and pig. Phytic acid is the nutritional constituent of animal diet but it is not digested by monogastric animals because they do not contain phytase enzyme in their intestines to break the phytic acid and due to this, phytic acid acts as an antinutritional chelating agent for various metal ions like $\mathrm{Ca}, \mathrm{Mg}$, Fe, $\mathrm{Zn}$, and etc., so that reduced the nutritive quality of food.

Objectives: Phytase is an important enzyme in the food/feed industry; therefore, isolation of phytase producing bacteria and optimization of phytase production on different parameters were performed in this study.

Materials and Methods: The present study was conducted in Biotechnology laboratory, Motilal Nehru National Institute of Technology, Allahabad, Uttar Pradesh, India. To isolate phytase producing bacteria from different soil samples like cattle shed, pulse crop field, poultry farms, and etc. $0.1 \mathrm{gr}$ of the soil samples were streaked on phytase screening medium. The qualitative screening of the isolates was performed on phytase screening medium plate with $1.5 \%$ agar, and phytase activity was determined by using shaking flask method. The best phytase producer was optimized using different parameters of phytase production.

Results: We isolated 32 phytase producing bacteria on phytase screening media. Upon screening of these strains, one of the best strain (DR6) which showed a $39 \mathrm{~mm}$ clear zone on phytase specific medium (PSM) was identified as Bacillus subtilis. So this strain was selected for further enzymatic assay and optimization. This strain showed $378 \mathrm{U} / \mathrm{mL}$ enzymatic activity upon enzymatic assay, the result of optimization of this best strain was performed at different parameters, and this strain showed best results at pH 5.5, Temp 50 ${ }^{\circ} \mathrm{Cwith}$ Glucose + Sucrose as Carbon source and Yeast extract as Nitrogen source.

Conclusions: The present study suggests that the enzyme obtained from strain B. subtilis can be used as feed supplement in animal diet also for reduction of phosphorus pollution problem in areas of livestock production.
\end{abstract}

Keywords: Phytase; Phytic Acid; Bacillus subtilis

\section{Background}

Phytic acid (myo-inositol 1, 2, 3, 4, 5, 6-hexa kis dihydrogen phosphate) is the storage form of phosphate in nature, and phytic acid is mostly present in cereals, nuts, legumes, and oil seeds (1-4). Most foods of plant origin contain $50 \%$ to $80 \%$ of their total phosphorus as phytate (5). Phytic acid reduced the availability of various metal ions such as Fe, $\mathrm{Zn}, \mathrm{Mg}$, Ca, and etc., thus reducing the nutritive quality of food $(6,7)$. Due to this, phytase enzyme is required to hydrolyze phytic acid. Phytases (myo-inositol hexa kis phosphate phosphohydrolase) also known as phytate hydrolyzing enzymes. It hydrolyses phytate and releases inorganic phosphate $(3,7-9)$.

Phytase enzyme is widely produced in nature by bacteria, fungi, yeast, plants, and animals. Phytase producing microorganisms are mostly present in rhizospheric soil of crop plants $(10,11)$. Monogastric animals like fish, poultry, pig, human,and etc., do not have sufficient levels of phytate-degrading enzymes in their digestive tracts to digest phytic acid, due to this phosphorus is not available to them (12). So feed is supplemented with inorganic phosphorus to meet phosphorous requirement. Hence Phytic acid acts as antinutrient constituent in plant-derived food and feed, because it forms complexes with proteins, amino acids, and various metal ions (13).

This is the main reason of human nutritional deficiencies of different metals like copper, zinc, iron, and etc., where plant food is staple food (14). The undigested phytate is excreted in excretions and poses a serious phosphorus pollution problem and this contributes to the eutrophication of water in areas of intensive livestock production. Due to this scenario phytase enzyme is re-

Implication for health policy/practice/research/medical education:

Isolation and identification of phytase producing bacteria and optimization of enzyme production would be helpful in enhancing bioavailable micronutrients in food grains and reducing phosphorus pollution.

Copyright (C) 2013, Ahvaz Jundishapur University of Medical Sciences; Licensee Kowsar Ltd. This is an Open Access article distributed under the terms of the Creative Commons Attribution License (http://creativecommons.org/licenses/by/3.0), which permits unrestricted use, distribution, and reproduction in any medium, provided the original work is properly cited. 
quired to overcome aforementioned problems as food and feed additive. The first commercial phytase product, which was available 10 years ago, offered animal nutritionists the tool to drastically reduce phosphorus excretion of monogastric animals (15).

According to Kornegay (16), phosphorus excretion can be reduced between $25 \%$ and $50 \%$ depending on diet, species and level of phytase supplementation. Nowadays there is no single phytase that is able to meet the diverse needs for all commercial and environmental applications. Therefore, there is an ongoing interest in screening microorganisms, including bacteria for novel phytases and also phytases play significant role in improving the nutritive quality of food and feed that contain phytic acid $(17,18)$. Hence phytase has a great industrial significance, and there is an ongoing interest in isolation of new $\mathrm{mi}$ crobial strain producing phytase and optimization of this enzyme (19).

\section{Objectives}

The principal goal of this study is to isolate the bacteria from different soil samples and optimize the production parameter to get the best bacterial strain.

\section{Materials and Methods}

\subsection{Isolation of Phytate Degrading Bacteria}

Bacterial strains were isolated from the soil samples collected from pulse fields, poultry farms, cattle shade, andetc., approximately $0.1 \mathrm{~g}$ of these samples were suspended in $5 \mathrm{ml}$ of $0.8 \%$ saline solution, and $0.1 \mathrm{ml}$ of this suspension was streaked on to phytase specific medium containing $1.5 \%$ glucose, $0.5 \%(\mathrm{NH} 4) 2 \mathrm{SO} 4,0.01 \%$ $\mathrm{NaCl}, 0.05 \% \mathrm{KCl}, 0.001 \% \mathrm{FeSO}$, 0.01\% MgSO4.7H2O, 0.01\% $\mathrm{CaCl} 2.2 \mathrm{H} 2 \mathrm{O}, 0.001 \% \mathrm{MnSO} 4$, pH 6.5 with $0.5 \%$ calcium phytate. 32 microbial colonies capable to hydrolyze calcium phytate which can be recognized by their surrounding clear halo were obtained by replating single colonies on phytase specific medium agar plate (4).

\subsection{Screening for Phytate Degrading Strains}

\subsubsection{Qualitative Screening of Phytase Producing Bacte- rial Strains}

Bacterial strains were assayed for qualitative screening by plate assay using phytase specific medium with $1.5 \%$ agar in petri plates. The halo zone and colony diameters were measured from 3 to 14 days of incubation at $28^{\circ} \mathrm{C}$ (20).

\subsubsection{Quantitative Screening of Phytase Producing Mi- croorganisms}

The isolated strains were inoculated in $50 \mathrm{ml}$ of phytase specific medium, and were cultured in a rotary shaker $(200 \mathrm{rpm})$ at $30^{\circ} \mathrm{C}$ for 3 days. Supernatant from $1 \mathrm{ml}$ of culture after centrifugation at $10000 \mathrm{~g}$ for $10 \mathrm{~min}$ at $4^{\circ} \mathrm{C}$, the clear supernatant was used as the source of extracellular phytases and used for the phytase activity assay. Calcium phytate was used as substrate for phytase activity assay. Phytase activity was determined by measuring the amount of liberated inorganic phosphate. The reaction mixture consisted of $0.5 \%$ calcium phytate prepared in sodium acetate buffer (0.1 M, pH 5.5), and $0.1 \mathrm{ml}$ of supernatant. After incubation at $45^{\circ} \mathrm{C}$ for $30 \mathrm{~min}$, the reaction was stopped by adding $5 \%$ trichloroacetic acid. The liberated phosphate ions were quantified by $500 \mu \mathrm{l}$ of $10 \mathrm{~N} \mathrm{H} 2 \mathrm{SO} 4,10 \%$ ammonium molybdate and 5\% FeSO 4 (4). After 30 min of incubation at $45^{\circ} \mathrm{C}$, absorbance was measured at $660 \mathrm{~nm}$. One enzyme unit (IU) was defined as the amount of enzyme liberating $1 \mu \mathrm{mol}$ of inorganic phosphate in $1 \mathrm{~min}$ under the assay conditions.

\subsection{Optimization of Culture Condition}

For determination of the optimum growth condition and phytase production, the best strain was inoculated into $50 \mathrm{ml}$ of liquid broth and incubated on shaker at $30^{\circ} \mathrm{C}$ for 5 days. Different carbon sources were tested such as $1.5 \%$ glucose, maltose, sucrose, fructose, lactose, and $0.75 \%$ glucose $+0.75 \%$ sucrose. Nitrogen sources were $0.5 \%$ yeast extract, ammonium sulphate, sodium nitrate, urea and ammonium acetate. $\mathrm{pH}$ gradient ranged from 3.5 to 8.5 , and temperature from $20^{\circ} \mathrm{C}$ to $70^{\circ} \mathrm{C}(19,21)$.

\subsubsection{Effect of Incubation Temperature}

To study optimal incubation temperature for maximum phytase production, the flask containing production medium was incubated at $20^{\circ} \mathrm{C}, 30^{\circ} \mathrm{C}, 40^{\circ} \mathrm{C}, 50^{\circ} \mathrm{C}$, $60^{\circ} \mathrm{C}$, and $70^{\circ} \mathrm{C}$ for 5 days keeping all other conditions at their optimum level.

\subsubsection{Effect of $p H$}

To optimize the initial $\mathrm{pH}$ of production medium the $\mathrm{pH}$ was 3.5. 4.5, 5.5, 6.5, 7.5 and 8.5 with $\mathrm{HCl}$ or $\mathrm{NaOH}$.

\subsection{Identification of Phytase Producing Bacteria}

Identification of best phytase producer bacterium was performed by both phenotypic and genotypic methods. Phenotypic method includes morphology and gram staining of bacteria. Genotypic identification of bacterium was performed by $16 \mathrm{~S}$ rDNA. Amplification of the 16 SrDNA region was performed using primers designed in the conserved region; the primers used were FD1 and $\mathrm{RP} 2$. Sequencing of the $\sim 1.5 \mathrm{~kb}$ region was performed using internal sequencing primers. Sequencing was performed with 5 different primers designed in the conserved regions on 16SrDNA, primers were as follows; 16SEQ2R, INS16SREV, 16SEQ3F, 16SEQ4F, and 16SEQ 4R. 


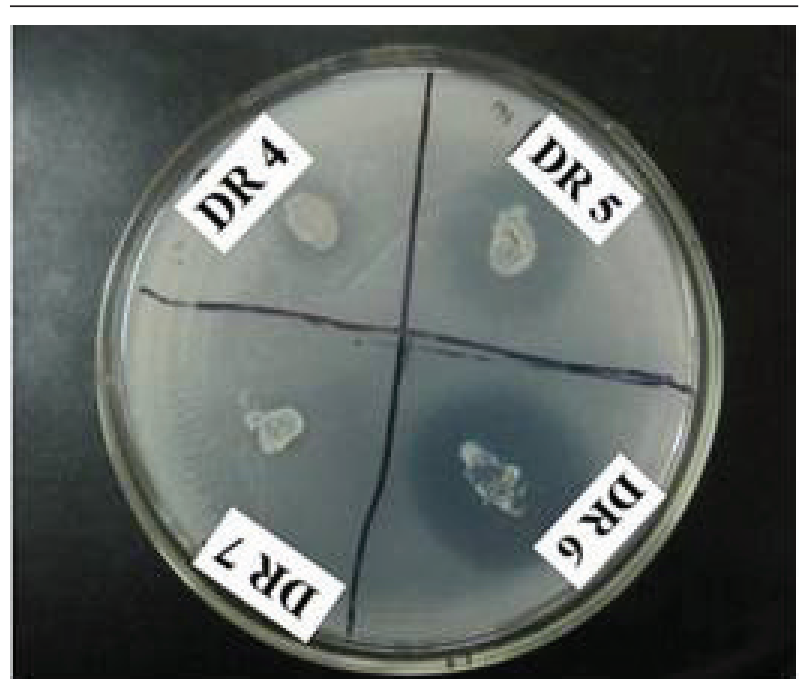

Figure 1. Strains Forming Peripheral Halo Zone Around Isolated Bacterial Colony on Phytase Specific Medium With Agar.

\section{Results}

\subsection{Isolation of Phytase Producing Bacteria}

The phytase producing Bacterial strains were isolated from phytase screening medium containing calcium phytate. 32 bacterial strains were isolated on the basis of clear halo zone on phytase specific agar medium around colonies. Strain DR6 was found to be the best strain and could produce about $39 \mathrm{~mm}$ clear halo zone around the colony (Figure 1).

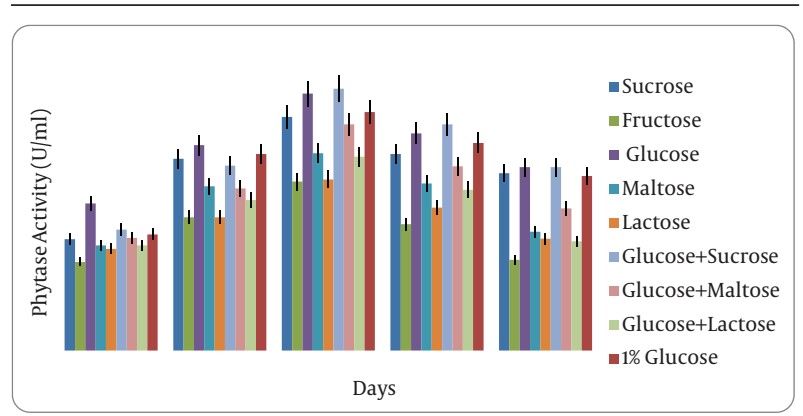

Figure 2. Optimization of Carbon Source for Phytase Production From Best Strain Showed That the Best Carbon Source Was Glucose + Sucrose Which Produced $381 \mathrm{U} / \mathrm{mL}$ Phytase Activity.

These isolated strains were subjected to quantitative screening by phytase assay. Strain DR6 showed maximum phytase activity of $378 \mathrm{U} / \mathrm{mL}$ on the third day of incubation (Table 1).

Table 1. Qualitative and Quantitative Screening of Different Phytase Producing Isolated Strains

\begin{tabular}{|c|c|c|c|c|c|}
\hline \multicolumn{6}{|c|}{ Enzyme activity $\mathrm{U} / \mathrm{mL}$} \\
\hline Carbon, Days & $\mathbf{1}$ & 2 & 3 & 4 & 5 \\
\hline $1 \%$ glucose & $169 \pm 0.87$ & $286 \pm 2.4$ & $347 \pm 1.6$ & $302 \pm 1.6$ & $254 \pm 1.4$ \\
\hline Sucrose & $162 \pm 1.6$ & $279 \pm 2$ & $340 \pm 2.3$ & $286 \pm 1.7$ & $258 \pm 1.4$ \\
\hline Fructose & $129 \pm 1.6$ & $194 \pm 1.3$ & $246 \pm 1$ & $184 \pm 1.5$ & $132 \pm 2.6$ \\
\hline Glucose & $214 \pm 1.6$ & $299 \pm 2$ & $374 \pm 1.5$ & $316 \pm 1.8$ & $267 \pm 2.1$ \\
\hline Maltose & $153 \pm 1.3$ & $239 \pm 1.7$ & $287 \pm 1$ & $243 \pm 2.6$ & $173 \pm 2.8$ \\
\hline Lactose & $148 \pm 2$ & $194 \pm 2$ & $249 \pm 2$ & $208 \pm 1.6$ & $163 \pm 2.4$ \\
\hline Glucose + Sucrose & $176 \pm 1.7$ & $269 \pm 1.7$ & $381 \pm 1.8$ & $329 \pm 1.3$ & $267 \pm 2.2$ \\
\hline Glucose + Maltose & $164 \pm 2.2$ & $236 \pm 2$ & $329 \pm 2.1$ & $268 \pm 1.1$ & $207 \pm 2.4$ \\
\hline Glucose + Lactose & $153 \pm 1.6$ & $219 \pm 2.5$ & $282 \pm 1.5$ & $234 \pm 1.2$ & $159 \pm 2.2$ \\
\hline
\end{tabular}

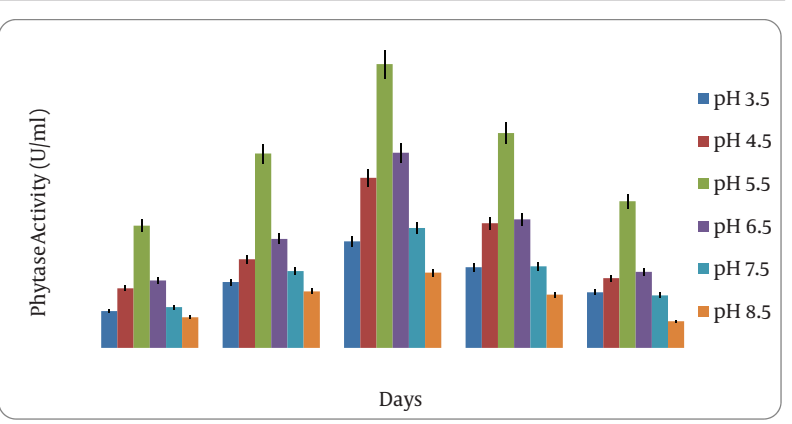

Figure 3. Optimization of $\mathrm{pH}$ Parameter for Phytase Production From Best Strain Showed That at pH 5.5 of Medium, P activity Was $362 \mathrm{U} / \mathrm{mL}$.

\subsection{Optimization of Culture Condition}

The parameters used for optimization of culture conditions were Carbon source, Nitrogen source, $\mathrm{pH}$, and temperature. Carbon sources like glucose, maltose, lactose, sucrose, fructose, and $0.75 \%$ glucose $+0.75 \%$ of different disaccharides were used for optimization. Strain showed optimum phytase activity of $381 \mathrm{U} / \mathrm{mL}$ on $0.75 \%$ glucose $+0.75 \%$ sucrose (Figure 2 ). $\mathrm{pH}$ gradient was taken from 3.5 to 8.5 in different flasks. On pH 5.5 this strain showed enzyme activity of $362 \mathrm{U} / \mathrm{mL}$ (Figure 3 ). Nitrogen sources used were $0.5 \%$ yeast extract, sodium nitrate, ammonium sulphate, urea and ammonium acetate. On yeast extract phytase activity was $398 \mathrm{U} / \mathrm{mL}$ (Figure 4). Temperature parameter was tested by using temperature range from 
$20^{\circ} \mathrm{C}$ to $70^{\circ} \mathrm{C}$. At $50^{\circ} \mathrm{C}$, strain showed enzyme activity of $387 \mathrm{U} / \mathrm{ml}$ phytase activity.

\subsection{Effect of Carbon Sources on Phytase Produc- tion: Carbon Isa Major Component of Cell}

The influence of different carbon sources on phytase production was shown in Table 2. Among different carbon sources studied, the highest yield of phytase was obtained with Glucose + Sucrose (381 U/mL).

\subsection{Effect of Nitrogen Sources on Phytase Produc- tion}

Among various organic and inorganic nitrogen sources better phytase production $(398 \mathrm{U} / \mathrm{mL}$ ) exhibited by yeast extract (Table 3).

\subsection{Effect of pH on Phytase Production}

It was found that maximum phytase production $(362 \mathrm{U} /$ $\mathrm{mL}$ ) was obtained at $\mathrm{pH} 6$ (Table 4). As the metabolic activities of microorganisms are sensitive to $\mathrm{pH}$ changes, phytase production was affected if the $\mathrm{pH}$ level was higher or lower compared to the optimum value.

\subsection{Effect of Temperature on Phytase Production}

The effect of incubation temperature was studied on phytase production (Table 5) and $50^{\circ} \mathrm{C}(387 \mathrm{U} / \mathrm{mL})$ was found to be optimum temperature.

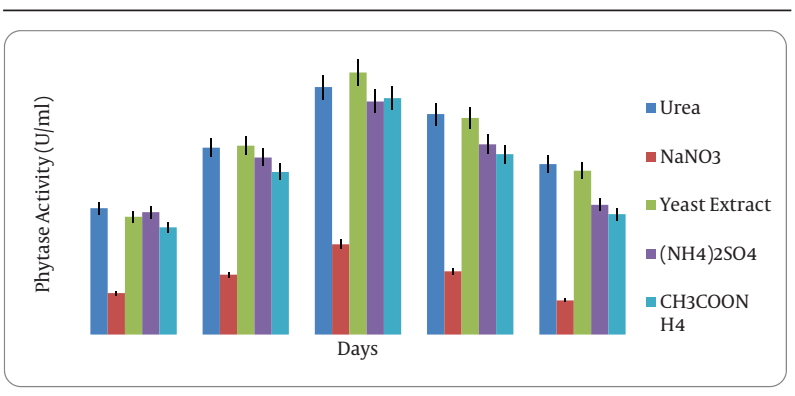

Figure 4. Optimization of Nitrogen Source for Phytase Production From Best Strain Showed That in Medium With Yeast Extract as N2 Source, Phytase Production Was $398 \mathrm{U} / \mathrm{mL}$

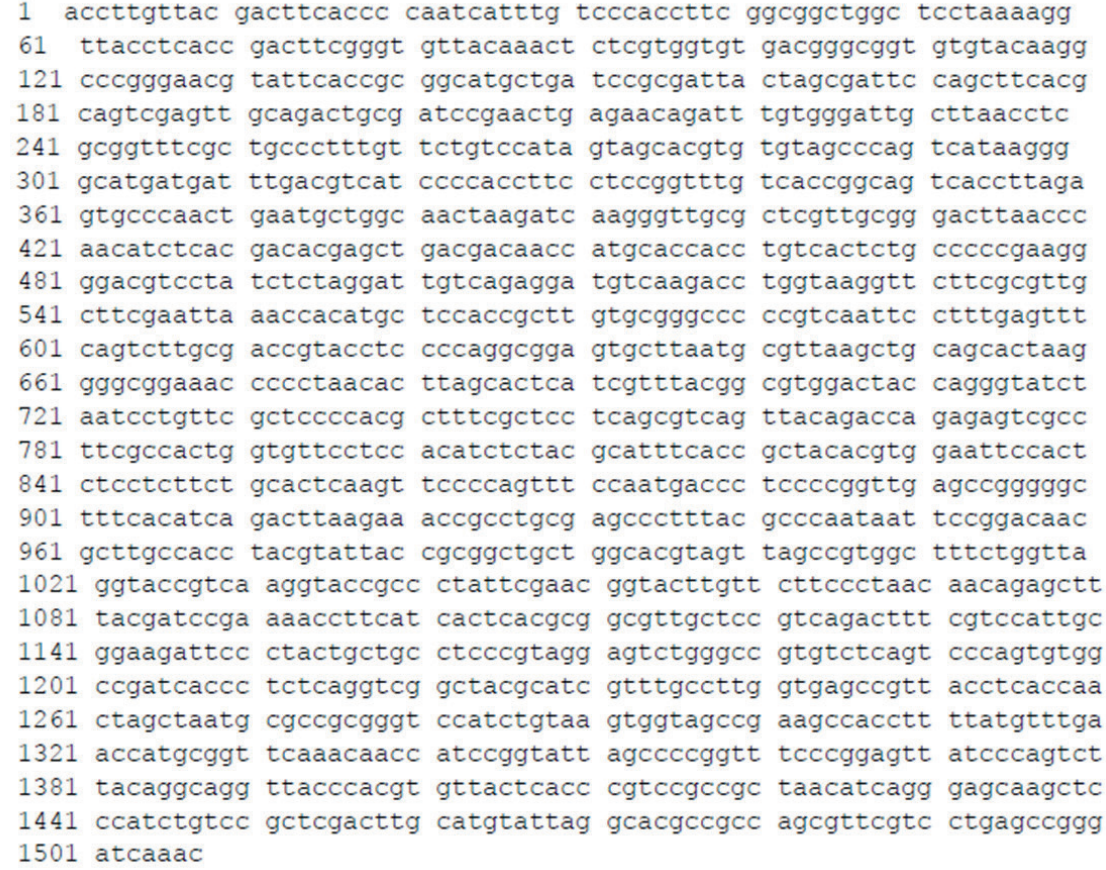

Figure 5. Identification by Genotypic Method (Molecular Characterization) 16S rDNA Sequence of Sample-DR 6 
Table 2. Effect of Carbon Sources on Phytase Production

\begin{tabular}{llllll}
\hline Enzyme Activity, U/mL & \multicolumn{3}{l}{} \\
\hline Carbon, Days & $\mathbf{1}$ & $\mathbf{2}$ & $\mathbf{3}$ & $\mathbf{4}$ & $\mathbf{5}$ \\
\hline 1\% glucose & $\mathbf{1 6 9} \pm \mathbf{0 . 8 7}$ & $\mathbf{2 8 6} \pm \mathbf{2 . 4}$ & $\mathbf{3 4 7} \pm \mathbf{1 . 6}$ & $\mathbf{3 0 2} \pm \mathbf{1 . 6}$ & $\mathbf{2 5 4} \pm \mathbf{1 . 4}$ \\
\hline Sucrose & $162 \pm 1.6$ & $279 \pm 2$ & $340 \pm 2.3$ & $286 \pm 1.7$ & $258 \pm 1.4$ \\
Fructose & $129 \pm 1.6$ & $194 \pm 1.3$ & $246 \pm 1$ & $184 \pm 1.5$ & $132 \pm 2.6$ \\
Glucose & $214 \pm 1.6$ & $299 \pm 2$ & $374 \pm 1.5$ & $316 \pm 1.8$ & $267 \pm 2.1$ \\
Maltose & $153 \pm 1.3$ & $239 \pm 1.7$ & $287 \pm 1$ & $243 \pm 2.6$ & $173 \pm 2.8$ \\
Lactose & $148 \pm 2$ & $194 \pm 2$ & $249 \pm 2$ & $208 \pm 1.6$ & $163 \pm 2.4$ \\
Glucose + Sucrose & $176 \pm 1.7$ & $269 \pm 1.7$ & $381 \pm 1.8$ & $329 \pm 1.3$ & $267 \pm 2.2$ \\
Glucose + Maltose & $164 \pm 2.2$ & $236 \pm 2$ & $329 \pm 2.1$ & $268 \pm 1.1$ & $207 \pm 2.4$ \\
Glucose + Lactose & $153 \pm 1.6$ & $219 \pm 2.5$ & $282 \pm 1.5$ & $234 \pm 1.2$ & $159 \pm 2.2$ \\
\hline
\end{tabular}

Table 3. Effect of Nitrogen Sources on Phytase Production

\begin{tabular}{llllll}
\hline \multicolumn{2}{l}{ Enzyme activity U/ml } & & & \\
N2Source, Days & Urea & NaNO3 & Yeast Extract & (NH4)2SO4 & CH3COONH4 \\
\hline $\mathbf{1}$ & $\mathbf{1 9 2} \pm \mathbf{1 . 7}$ & $\mathbf{6 3} \pm \mathbf{1 . 3}$ & $\mathbf{1 7 9} \pm \mathbf{1 . 7}$ & $\mathbf{1 8 6} \pm \mathbf{0 . 6}$ & $\mathbf{1 6 3} \pm \mathbf{1 . 2}$ \\
\hline $\mathbf{2}$ & $284 \pm 3.3$ & $91 \pm 1.2$ & $287 \pm 1.7$ & $269 \pm 1.2$ & $247 \pm 1.3$ \\
$\mathbf{3}$ & $376 \pm 1.2$ & $137 \pm 1.3$ & $398 \pm 0.3$ & $354 \pm 1.5$ & $359 \pm 1.9$ \\
$\mathbf{4}$ & $335 \pm 3.2$ & $96 \pm 1.5$ & $329 \pm 1.3$ & $289 \pm 1.3$ & $274 \pm 1$ \\
$\mathbf{5}$ & $259 \pm 2$ & $52 \pm 1.5$ & $249 \pm 0.9$ & $197 \pm 1.3$ & $183 \pm 1.5$ \\
\hline
\end{tabular}

Table 4. Effect of pH on Phytase Production

\begin{tabular}{lllllll}
\hline \multicolumn{7}{c}{ Enzyme activity U/mL } \\
\hline pH, Days & $\mathbf{3 . 5}$ & $\mathbf{4 . 5}$ & $\mathbf{5 . 5}$ & $\mathbf{6 . 5}$ & $\mathbf{7 . 5}$ & $\mathbf{8 . 5}$ \\
\hline $\mathbf{1}$ & $\mathbf{4 7} \pm \mathbf{1 . 3}$ & $\mathbf{7 6} \pm \mathbf{1 . 3}$ & $\mathbf{1 5 6} \pm \mathbf{1 . 3}$ & $\mathbf{8 6} \pm \mathbf{1 . 6}$ & $\mathbf{5 2} \pm \mathbf{1 . 5}$ & $\mathbf{3 9} \pm \mathbf{1 . 4}$ \\
\hline $\mathbf{2}$ & $84 \pm 1.5$ & $113 \pm 1.6$ & $248 \pm 2$ & $139 \pm 2.3$ & $98 \pm 1.3$ & $72 \pm 2.1$ \\
$\mathbf{3}$ & $136 \pm 1.4$ & $217 \pm 1.4$ & $362 \pm 1.4$ & $249 \pm 2.5$ & $153 \pm 1.5$ & $96 \pm 1.6$ \\
$\mathbf{4}$ & $103 \pm 1.3$ & $159 \pm 2$ & $274 \pm 1.5$ & $164 \pm 1.6$ & $104 \pm 2$ & $68 \pm 1.4$ \\
$\mathbf{5}$ & $71 \pm 1.4$ & $89 \pm 2.4$ & $187 \pm 1.7$ & $97 \pm 1.3$ & $67 \pm 1.4$ & $34 \pm 1.4$ \\
\hline
\end{tabular}

Table 5. Effect of Temperature on Phytase Production

\begin{tabular}{ll}
\hline Temperature,${ }^{\circ} \mathbf{C}$ & Activity, U/mL \\
\hline $\mathbf{2 0}$ & $\mathbf{6 9} \pm \mathbf{1 . 7}$ \\
\hline $\mathbf{3 0}$ & $127 \pm 1.4$ \\
$\mathbf{4 0}$ & $264 \pm 2.3$ \\
$\mathbf{5 0}$ & $387 \pm 2$ \\
$\mathbf{6 0}$ & $219 \pm 2.2$ \\
$\mathbf{7 0}$ & $83 \pm 1.4$ \\
\hline
\end{tabular}

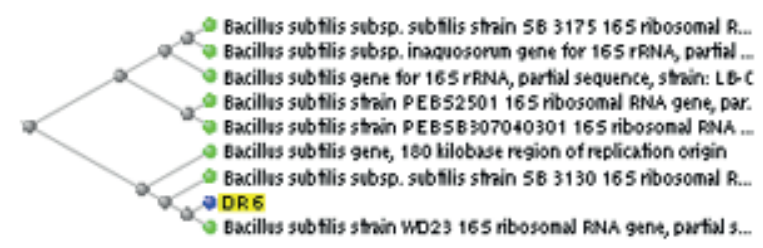

Figure 6. Phylogenetic Dendrogram16S rDNA Sequence of B. subtilis DR6 


\subsection{Identification by Phenotypic Method (Morpho-logical Characterization) and Genotyp- ic (Molecular Characterization)}

Bacillus subtilis DR6 is a Gram positive and rod shaped bacterium. The isolated strain DR6 has been characterized by 16 SrDNA sequence. The DR6 was showed nearest relationship with Bacillus sp. on the basis of phylogenetic analysis (Figure 5 and 6)

\section{Discussion}

In the present study, we isolated 32 bacterial strains on the basis of formation of zone around bacterial colony. One of the best strains showing highest phytase activity was selected for optimization of phytase production. On the basis of results of optimization on different parameters, this strain can be used for phytase production on industrial scale. The optimum productivity of phytase by our best bacterial isolate (B. subtilis DR6) was achieved with optimized process parameter such as Glucose $+\mathrm{Su}$ crose as carbon source, yeast extract as nitrogen source, incubation temperature of $500^{\circ} \mathrm{C}$, initial $\mathrm{pH}$ of 5.5 , and incubation period of 3 days. As well as phytase produced by this strain can be used as feed supplement in animal diet, also for reduction of phosphorus pollution problem in areas of livestock production.

\section{Acknowledgements}

The authors would like to thanks Prof. H. S. Dhaliwal for provide the concept and valuable suggestions of this study. The authors are grateful to Department of Science and Technology, New Delhi and Ministry of Human Resource \& Development, Government of India, New Delhi for providing financial support.

\section{Authors' Contribution}

None declared.

\section{Financial Disclosure}

There is no Financial Disclosure for this study.

\section{Funding/Support}

Department of Science and Technology (DST), New Delhi.

\section{References}

1. Bae HD, Yanke LJ, Cheng KJ, Selinger LB. A novel staining method for detecting phytase activity. J Microbiol Methods. 1999;39(1):1722.

2. Chang $\mathrm{CH}$, Pei HW, Ching $\mathrm{TH}$, Kou JCH. A Pichia postoris fermentation strategy for the heterologus expression of an Escherichia coli phytase. Enzyme Microbiol Technol. 2004;35:315-320.

3. Han YW, Gallagher DJ, Wilfred AG. Phytase production byAspergillus ficuum on semisolid substrate. J industrial Microbiol. 1987;2(4):195-200.
4. Quan C, Zhang L, Wang Y, Ohta Y. Production of phytase in a low phosphate medium by a novel yeast Candida krusei. J Biosci Bioeng. 2001;92(2):154-60.

5. Harland Barbara F, Morris Eugene R. Phytate: A good or a bad food component? Nutr Res. 1995;15(5):733-754.

6. Bindu S, Somashekar D, Joseph R. A comparative study on permeabilization treatments for in situ determination of phytase of Rhodotorula gracilis. Lett Appl Microbiol.1998;27(6):336-340.

7. El-Batal AI, Abdel Karem H. Phytase production and phytic acid reduction in rapeseed meal by Aspergillus niger during solid state fermentation. Food Res Int. 2001;34(8):715-720.

8. Cho JS, Lee CW, Kang SH, Lee JC, Bok JD, Moon YS, et al. Purification and characterization of a phytase from Pseudomonas syringae MOK1. Curr Microbiol. 2003;47(4):290-4.

9. Konietzny Ursula, Greiner Ralf. Molecular and catalytic properties of phytate-degrading enzymes (phytases). Int J Food sci Technol. 2002;37(7):791-812.

10. Igual José Mariano, Valverde Angel, Cervantes Emilio, Velázquez Encarna. Phosphate-solubilizing bacteria as inoculants for agriculture: use of updated molecular techniques in their study. Agronomie. 2001;21(2):561-568.

11. Konietzny Ursula, Greiner Ralf. Bacterial phytase: potential application, in vivo function and regulation of its synthesis. Brazil Microbiol. 2004;35(1-2):12-18.

12. Mittal Arpana, Singh Gulab, Goyal Varsha, Yadav Anita, RaiAneja Kamal, KumarGautam Sanjeev, et al. Isolation and biochemical characterization of acido-thermophilic extracellular phytase producing bacterial strain for potential application in poultry feed. Jundishapur J Microbiol. 2012;4(4):-

13. Pallauf J, Rimbach G. Nutritional significance of phytic acid and phytase. Arch Tierernahr.1997;50(4):301-19.

14. Manary MJ, Krebs NF, Gibson RS, Broadhead RL, Hambidge KM. Community-based dietary phytate reduction and its ef fect on iron status in Malawian children. Ann Trop Paediatr 2002;22(2):133-6.

15. Haefner S, Knietsch A, Scholten E, Braun J, Lohscheidt M, Zelder O. Biotechnological production and applications of phytases. Appl Microbiol Biotechnol. 2005;68(5):588-97.

16. Yi Z, Kornegay ET, Ravindran V, Lindemann MD, Wilson JH. Effectiveness of Natuphos phytase in improving the bioavailabilities of phosphorus and other nutrients in soybean meal-based semipurified diets for young pigs. JAnim Sci. 1996;74(7):1601-11.

17. Alconada TM, Martínez MJ. Purification and characterization of a $\beta$-glucosidase from the phytopathogenic fungus Fusarium oxysporum f. sp. melonis. Lett Appl Microbiol. 1996;22(2):106-110.

18. Ugwuanyi JObeta, McNeil Brian, Harvey LindaM, Nigam Poonam, Pandey Ashok. Production of Protein-Enriched Feed Using Agro-Industrial Residues as Substrates. In: Ugwuany JObeta, McNeil Brian, Harvey LindaM, Nigam Poonam, Pandey Ashok, editors.Biotechnology for Agro-Industrial Residues Utilisation.Springer Netherlands; 2009. p. 77-103.

19. Lan GQ, Abdullah N, Jalaludin S, Ho Y. Optimization of carbon and nitrogen sources for phytase production by Mitsuokella jalaludinii, a new rumen bacterial species. Lett Appl Microbiol. 2002;35(2):157-61.

20. Rodriguez H, Fraga R. Phosphate solubilizing bacteria and their role in plant growth promotion. Biotechnol Adv. 1999;17(4-5):31939.

21. Jorquera MilkoA, Hernández MarcelaT, Rengel Zed, Marschner Petra, Luz Mora María. Isolation of culturable phosphobacteria with both phytate-mineralization and phosphate-solubilization activity from the rhizosphere of plants grown in a volcanic soil. Biol Fertil Soil. 2008;44(8):1025-1034.

Please cite this paper as:Singh NK, Joshi DK, Gupta RK. Isolation of Phytase Producing Bacteria and Optimization of Phytase Production Parameters. Jundishapur J Microbiol. 2013; 6(5):e6419. DOI: $10.5812 / j j m .6419$ 